\title{
DEPRESSION BY INBREEDING AFTER FOUR SUCESSIVE SELF-POLLINATION SQUASH GENERATIONS
}

\author{
Antonio Ismael Inácio Cardoso \\ UNESP/FCA - Depto. de Produção Vegetal, C.P. 237 - 18603-970 - Botucatu, SP - Brasil. \\ E-mail <ismaeldh@fca.unesp.br>
}

\begin{abstract}
The strategy for breeding $\mathrm{F}_{1}$ hybrid squash is to develop parental lines through self-pollination. However, it increases plant mean homozygosis, which is not the natural genetic state of a cross-pollinated species, and can cause "inbreeding depression". The objective of this work was to evaluate this depression with sucessive generations of self-pollination (without selection) in Cucurbita moschata, cv. Piramoita. Populations were obtained from lines with one to four generations of self-pollination (obtained by the SSD method), from the original cv. Piramoita (population $\mathrm{S}_{0}$ ). Randomized blocks were used with five treatments (different generations of self-pollination $-\mathrm{S}_{0}$ to $\mathrm{S}_{4}$ ), six replicates and five plants per plot. Regression analysis was made by the Wright inbreeding coefficient (F) to measure the homozygosis level effect on vigor loss. There was a linear reduction of mean weight and fruit length, seed production (number and weight) per fruit with the increase of the homozygosis level; however inbreeding did not affect seed quality (weight of 100 seeds and germination).
\end{abstract}

Key words: Cucurbita moschata, cucurbits, selfing

\section{DEPRESSÃO POR ENDOGAMIA APÓS QUATRO GERAÇÕES SUCESSIVAS DE AUTOPOLINIZAÇÃO EM ABÓBORA}

\begin{abstract}
RESUMO: A estratégia utilizada no melhoramento genético visando híbridos $\mathrm{F}_{1}$ em abóbora é a obtenção de linhagens por autopolinização. Entretanto, a autopolinização aumenta a homozigose média das plantas, que não é a condição genética natural de espécies alógamas, e pode causar a "depressão por endogamia". Este trabalho teve como objetivo verificar se existe depressão por endogamia com sucessivas gerações de autofecundação (sem seleção) em abóbora cultivar Piramoita. Foram obtidas populações a partir da mistura de linhagens com uma a quatro gerações de autofecundação (obtidas pelo método SSD), a partir da população original 'Piramoita' $\left(\mathrm{S}_{0}\right)$. O delineamento experimental utilizado foi em blocos ao acaso com cinco tratamentos (diferentes gerações de autofecundação $-\mathrm{S}_{0}$ a $\mathrm{S}_{4}$ ), seis repetições e cinco plantas por parcela. Realizou-se análise de regressão, utilizando-se o coeficiente de endogamia de Wright (F) para medir o efeito do nível de homozigose sobre a perda de vigor. Houve redução linear do peso médio e comprimento de fruto e produção (número e peso) de sementes por fruto com o aumento no nível de homozigose. Entretanto a endogamia não afetou a qualidade das sementes (peso de 100 sementes e germinação).

Palavras-chave: Cucurbita moschata, cucurbitáceas, auto-fecundação
\end{abstract}

\section{INTRODUCTION}

The strategy for breeding $F_{1}$ hybrid squash is to develop parental lines through self-pollination (Whitaker \& Robinson, 1986; Della Vecchia et al., 1993; Robinson \& Decker-Walters, 1999; Cardoso, 2001; Maluf, 2001). However, self-pollination increases plant mean homozygosis, which is not the natural genetic state of a crosspollinated species, and it can cause "inbreeding depression". This is clearly observed in hybrid corn production, when plant size and vigor of self-pollinated inbred lines are drastically reduced as compared to outbreeding cultivars from which they originated (Allard, 1971).

Although most cross-pollinated species have higher or lower levels of inbreeding depression as a con- sequence of inbreeding, there are some in which self-pollination can happen in a continuous way with no vigor loss. Cucurbits, being cross-pollinated, are an example of a group of species in which certain lines seem to lose little vigor by inbreeding (Allard, 1971; Whitaker \& Robinson, 1986; Robinson, 1999).

Despite the absense of inbreeding depression, the use of cucumber hybrids is very common, and inbred lines may be used directly as cultivars, when the objective is fruit productivity and quality (Cramer \& Wehner, 1999). In some aspects, research results are contradictory regarding loss of vigor in inbred cucurbits. Self-pollination for 10 generations of Cucurbita maxima did not affect vigor or reproductive capacity (Cummings, 1928). Studying the effect of inbreeding for $C$. pepo, Bushnell 
(1922) observed that vigor loss during self-pollination did not necessarily occur.

Although several authors assume the hypothesis of reduced inbreeding depression in Cucurbita, some researchers have shown inbreeding depression for several characteristics of $C$. pepo and C. maxima (Borghi et al., 1973; Chekalina, 1976). Johannsson et al. (1998) reported decreased fruit yield and pollen performance by inbreeding of $C$. texana. Inbreeding may also affect pollen quality of $C$. pepo (Stephenson et al., 2001).

Cucumber, squash, melon and watermelon lines with no vigor loss have been developed. Inbreeding depression is not a limiting factor for hybrid seed production of cucurbits, in spite of being cross-pollinated. However, some lines can have decreased vigor and yield (Robinson, 1999). The present work evaluates the inbreeding depression with sucessive self-pollination for Cucurbita moschata, cv. Piramoita.

\section{MATERIAL AND METHODS}

The experiment was carried out in São Manuel, SP,

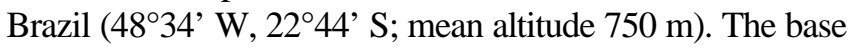
population was cv. Piramoita, obtained from four backcrosses after the $\mathrm{F}_{2}$ generation of the interspecific cross between C. pepo ('Yankee Hybrid') x C. moschata ('Butternut') with C. moschata ('Menina Brasileira'), to incorporate the "bush" character into the last species (Costa, 1974).

Five treatments were arranged in randomized blocks with six replicates of five plants. Treatments were: population $\mathrm{S}_{0}$ (cultivar Piramoita) and four inbred "populations" obtained from sucessive self-pollinations $\left(\mathrm{S}_{1}, \mathrm{~S}_{2}\right.$, $\mathrm{S}_{3}$ and $\mathrm{S}_{4}$ ), with no plant selection. The single seed descent (SSD) method was used. Each population was obtained by mixing seeds of all progenies existing in each generation of self-pollination. Each progeny participated with the same number of seeds in order to obtain representative "populations" of each generation.

Seeding was made on January 3, 2002 and the transplant on January 23,2002 , using a $2.0 \times 1.0 \mathrm{~m}$ spac- ing. Two harvests were carried out when the fruits were cream-colored, defined as morphological ripening, on April 10 and 17. Before seed extraction, the fruits were stored during seven days to complete seed ripening.

Fruit mean weight, total, neck and bulbous seed cavity length (obtaining the ratio neck length/bulbous length), seed yield per fruit (number and weight), weight of 100 seeds and \% seed germination were determined. After analysis of variance, the means were compared by the Tukey test $(P=0.05)$. For the characteristics with statistical difference among the treatments (inbred populations), regression analysis was carried out using the Wright's inbreeding coefficient $(F)$ to measure the homozygosis level effect on the assessed characteristics (Rubino \& Wehner, 1986).

\section{RESULTS AND DISCUSSION}

Fruits presented much lower mean weight for all inbred populations than in the original population $S_{0}$ as a consequence of reduced fruit length (Table 1). Such reduction was higher for neck length and lower for bulbous length, where seeds are located. This can be noticed by the reduction in the ratio between neck and bulbous length (Table 1). Chekalina (1976) had already reported a reduction in fruit weight of different cultivars of $C$. maxima and $C$. pepo, as a result of inbreeding depression after three generations of self-pollination.

Inbred populations also presented reduced seed yield (Table 2). However, seed quality was not affected, and seeds had the same 100 -seed weight and percent germination as the $\mathrm{S}_{0}$ population. Inbreeding was harmful to seed yield but not to quality. Schuster et al. (1974), cited by Robinson (1999), had also observed that the most significant inbreeding depression effect on $C$. pepo was reduction in seed yield.

Vigor loss was observed in the first generation of self-pollination, contrarily to Chekalina (1976) who reported reduced vigor only after the second or third generations of inbreeding. Considering an increment of 50\%

Table 1 - Fruit mean weight, total, neck and bulbous seed cavity (BSC) length, and relation between neck and bulbous length in populations with different inbreeding levels. São Manuel-SP, 2002.

\begin{tabular}{lcccccc}
\hline Population & $\begin{array}{c}\text { Wright's coefficient } \\
\text { of inbreeding }\end{array}$ & $\begin{array}{c}\text { Fruit mean } \\
\text { weight }\end{array}$ & $\begin{array}{c}\text { Fruit total } \\
\text { length }\end{array}$ & BSC length & Neck length & $\begin{array}{c}\text { Neck / Bulbous } \\
\text { length }\end{array}$ \\
\hline S0 & 0.00 & $1340 \mathrm{a}^{1}$ & $33.6 \mathrm{a}$ & $11.1 \mathrm{a}$ & $22.6 \mathrm{a}$ & $2.05 \mathrm{a}$ \\
$\mathrm{S} 1$ & 0.50 & $921 \mathrm{~b}$ & $27.2 \mathrm{~b}$ & $9.9 \mathrm{ab}$ & $17.3 \mathrm{~b}$ & $1.75 \mathrm{ab}$ \\
S2 & 0.75 & $801 \mathrm{~b}$ & $24.6 \mathrm{~b}$ & $9.3 \mathrm{~b}$ & $15.3 \mathrm{~b}$ & $1.66 \mathrm{ab}$ \\
S3 & 0.88 & $949 \mathrm{~b}$ & $26.1 \mathrm{~b}$ & $10.1 \mathrm{ab}$ & $15.9 \mathrm{~b}$ & $1.57 \mathrm{~b}$ \\
S4 & 0.94 & $890 \mathrm{~b}$ & $22.7 \mathrm{~b}$ & $9.2 \mathrm{~b}$ & $13.5 \mathrm{~b}$ & $1.46 \mathrm{~b}$ \\
\hline C. V. ${ }^{2}$ & & $20.5 \%$ & $10.7 \%$ & $8.8 \%$ & $14.3 \%$ & $7.7 \%$ \\
\hline
\end{tabular}

${ }^{1}$ Means followed by the same letter do not differ by the Tukey test (5\%)

${ }^{2}$ Coefficient of variance 
Table 2 - Weight of 100 seeds, seed yield and quality of populations with different inbreeding levels. São Manuel-SP, 2002.

\begin{tabular}{|c|c|c|c|c|c|}
\hline Population & Wright's coefficient of inbreeding & Weight of 100 seeds & Seed number / fruit & Seed yield / fruit & Germination \\
\hline & & g & & $\mathrm{g}$ & $\%$ \\
\hline So & 0.00 & $7.93 \mathrm{a}^{1}$ & $242 \mathrm{a}$ & $19.1 \mathrm{a}$ & $74 \mathrm{a}$ \\
\hline $\mathrm{S} 1$ & 0.50 & $8.41 \mathrm{a}$ & $150 \mathrm{~b}$ & $12.7 \mathrm{~b}$ & 82 a \\
\hline S2 & 0.75 & $7.96 \mathrm{a}$ & $132 \mathrm{~b}$ & $10.5 \mathrm{~b}$ & $74 \mathrm{a}$ \\
\hline S3 & 0.88 & $7.58 \mathrm{a}$ & $166 \mathrm{~b}$ & $12.6 \mathrm{~b}$ & 68 a \\
\hline $\mathrm{S} 4$ & 0.94 & $7.63 \mathrm{a}$ & $138 \mathrm{~b}$ & $10.6 \mathrm{~b}$ & $81 \mathrm{a}$ \\
\hline $\mathrm{CV}^{2}$ & & $8.4 \%$ & $9.1 \%$ & $11.5 \%$ & $9.3 \%$ \\
\hline
\end{tabular}

${ }^{1}$ Means followed by the same letter do not differ by the Tukey test (5\%)

${ }^{2}$ Coefficient of variance

Table 3 - Linear regression analyses obtained for populations of different inbreeding levels. São Manuel-SP, 2002.

\begin{tabular}{lcc}
\hline Characteristic & Regression equation & $\mathrm{R}^{2}$ \\
\hline Fruit mean weight & $\mathrm{Y}=1269-471 . \mathrm{X}^{1}$ & $0.62^{* * 2}$ \\
Fruit total length & $\mathrm{Y}=33.2-10.4 . \mathrm{X}$ & $0.78^{* *}$ \\
Bulbous seed cavity length & $\mathrm{Y}=10.9-1.6 . \mathrm{X}$ & $0.55^{* *}$ \\
Neck length & $\mathrm{Y}=22.3-8.7 . \mathrm{X}$ & $0.79^{* *}$ \\
$\begin{array}{l}\text { Bulbous seed cavity / neck } \\
\text { length }\end{array}$ & $\mathrm{Y}=2.05-0.57 . \mathrm{X}$ & $0.66^{* *}$ \\
Seed yield (g/fruit) & $\mathrm{Y}=18.3-8.5 . \mathrm{X}$ & $0.72^{* *}$ \\
\hline Number of seed per fruit & $\mathrm{Y}=227-100 . \mathrm{X}$ & $0.71^{* *}$ \\
\hline${ }^{1} \mathrm{X}$ is the Wright's inbreeding coefficient $(\mathrm{F})$ & \\
${ }^{2 * *}$ significant by the t test at $1 \%$ &
\end{tabular}

in homozygotes in each generation of self-pollination, higher loss in the first generation, decreasing in subsequent generations, is expected. This trend was observed in all characteristics with vigor loss, since the results followed a linear regression model, with values decreasing with increasing homozygosis, evaluated through Wright's coefficient (Table 3).

Little vigor loss by inbreeding in cucurbits is attributed to small population maintenance because of their need for space. Consequently, this results in inbreeding in spite of the fact that floral biology favors cross-pollination (Allard, 1971). However, the studied population was originated from an interspecific cross $(C$. pepo x $C$. moschata), involving three cultivars (Yankee Hybrid, Butternut and Menina Brasileira), without self-pollination in the end of the program (Costa, 1974), a fact that probably resulted in great genetic variability and high quantity of heterozygous loci. The incorporated bush character favors an increase of plant number per area, reducing the chance of natural self-pollinations during seed maintenance and multiplication phases. This may be the reason for high depression in this population.

By the single seed descent method, lines obtained will hardly be more productive than the original population. However, mean of the populations with different inbreeding levels were assessed, because lines obtained after a certain number of generations of self-pollination may present different results in relation to vigor loss (Maluf, 2001). This experiment evaluated the progeny mixtures, which presented reduced mean weight and fruit size, and lower seed yield. Nevertheless, there may exist progenies in which there is no loss as compared to the original $S_{0}$ population. Moreover, low-vigour, inbred progenies may generate populations or vigorous hybrids after heterozygosity recovery. Seed yield, however, can be damaged by lower seed production in lines, affecting their final cost. Vigor loss in Cucurbita moschata, cv. Piramoita, with successive generations of self-pollination, does not prevent its use for obtaining lines in breeding programs.

\section{ACKNOWLEDGEMENT}

To FAPESP for financial support (process 98/ 14834-9) and to FUNDUNESP for translation support.

\section{REFERENCES}

ALLARD, R.W. Princípios do melhoramento genético das plantas. São Paulo: Edgard Blüchner, 1971. 381p.

BORGHI, B.; MAGGIORI, T.; BOGGINI, G.; BOLANI, F. Inbreeding depression and heterosis in Cucurbita pepo evaluated by means of diallelical analysis. Genetika Agraria, v.27, p.415-431, 1973.

BUSHNELL, J.W. Isolation of uniform types of hubbard squash by inbreeding. Proceedings of American Society for Horticultural Science, v.19, p.139-144, 1922.

CARDOSO, A.I.I. Melhoramento de hortaliças. In: NASS, L.L.; VALOIS, A.C.C.; MELO, I.S.; VALADARES, M.C. (Ed.) Recursos genéticos e melhoramento: plantas. Rondonópolis: Fundação MT, 2001. cap.12, p.293-325.

CHEKALINA, I.N. Effect of inbreeding on variability of cucurbits (Cucurbita maxima Dusch and Cucurbita pepo L.) Genetika, v.12, p.4549, 1976.

COSTA, C.P. Obtenção de abobrinha Menina Brasileira (Cucurbita moschata) com hábito de crescimento tipo moita e com tolerância ao mosaico da melancia. Relatório Científico do Instituto de Genética, v.8, p.61-62, 1974.

CRAMER, C.S.; WEHNER, T.C. Little heterosis for yield and yield components in hybrids of six cucumber inbreds. Euphytica, v.110, p.99$108,1999$.

CUMmings, M.B. Pure lines studies with ten generations of hubbard squash. Vermont: Agricultural Experimental Station, 1928. 29p. (Bulletim, 280).

DELLA VECCHIA, P.T.; TERENCIANO SOBRINHO, P.; TERENCIANO, A. Breeding bush types of C. moschata with field resistance to PRSVw. Cucurbit Genetics Cooperative, v.16, p.70-71, 1993. 
JOHANNSSON, M.H.; GATES, M.J.; STEPHENSON, A.G. Inbreeding depression affects pollen performance in Cucurbita texana. Journal of Evolutionary Biololy, v.11, p.579-588, 1998.

MALUF, W.R. Heterose e emprego de híbridos F1 em hortaliças. In: NASS, L.L.; VALOIS, A.C.C.; MELO, I.S.; VALADARES, M.C. (Ed.) Recursos genéticos e melhoramento: plantas. Rondonópolis: Fundação MT, 2001. cap.13, p.327-356.

ROBINSON, R.W. Rationale and methods for producing hybrid cucurbit seed. Journal of New Seeds, v.1, p.1-47, 1999.

ROBINSON, R.W.; DECKER-WALTERS, D.S. Cucurbits. Cambridge: CAB International, 1999. 226p.

RUBINO, D.B.; WEHNER, T.C. Effect of inbreeding on horticultural performance of lines developed from an open-pollinated cucumber population. Euphytica, v.35, p.459-464, 1986.
STEPHENSON, A.G.; HAYES, C.N.; JOHANNSSON, M.H.; WINSOR, J.A. The performance of microgametophytes is affected by inbreeding depression and hybrid vigor in the sporophytic generation. Sexual Plant Reproduction, v.14, p.77-83, 2001.

WHITAKER, T.W.; ROBINSON, R.W. Squash breeding. In. BASSET, M.J. (Ed.) Breeding vegetable crops. Westport: Avi Publishing Company, 1986. cap.6, p.209-242.

Received May 22, 2003

Accepted November 13, 2003 